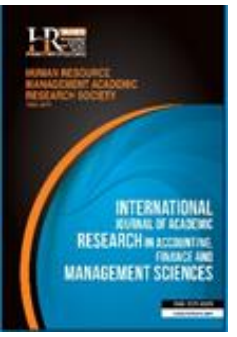

International Journal of Academic Research in Accounting, Finance and Management Sciences

Vol. 8, No.4, October 2018, pp. 70-80

E-ISSN: 2225-8329, P-ISSN: 2308-0337

(C) 2018 HRMARS

www.hrmars.com

To cite this article: Al Sharairi, J.A. (2018). The Affecting Factors in the Improving of Financial Performance in Al AlBayt University: Evidence From Jordan, International Journal of Academic Research in Accounting, Finance and Management Sciences 8 (4): 70-80.

\title{
The Affecting Factors in the Improving of Financial Performance in Al Al-Bayt University: Evidence from Jordan
}

\author{
Jamal Adel Al Sharairi
}

Al al-Bayt University, Mafraq-Jordan, E-mail: jamalsharairi@yahoo.com

Abstract

The study aimed at explaining the factors affecting the improvement of financial performance at Al-Bayt University. Sixty questionnaires were distributed to the employees of the university, who are related to finance, accounting and auditing. Forty-five samples were suitable for analysis, with a recovered percentage of $75 \%$. The data of the questionnaires had been analyzed by using (SPSS), and a number of statistical methods through descriptive statistics, arithmetic means, standard deviations, percentages, hypotheses of the study were tested by testing multi regression. The study found the presence of impact of the "increase revenue to improve the financial performance of Al-Bayt University variable", the study recommended a number of recommendations, namely: The need to develop new disciplines at Al-Bayt University that are required in the local and Arab labor market.

Key words

Competence, workload, motivation, employee performance

\begin{tabular}{|c|c|c|}
\hline Received: & 25 Dec 2018 & (C) The Authors 2018 \\
\hline Revised: & 13 Jan 2019 & Published by Human Resource Management Academic Research Society (www.hrmars.com) \\
\hline $\begin{array}{l}\text { Accepted: } \\
\text { d Online: }\end{array}$ & $\begin{array}{l}22 \text { Jan } 2019 \\
06 \text { Feb } 2019\end{array}$ & $\begin{array}{l}\text { This article is published under the Creative Commons Attribution (CC BY 4.0) license. Anyone may } \\
\text { reproduce, distribute, translate and create derivative works of this article (for both commercial and non- } \\
\text { commercial purposes), subject to full attribution to the original publication and authors. The full terms of } \\
\text { this license may be seen at: http://creativecommons.org/licences/by/4.0/legalcode }\end{array}$ \\
\hline
\end{tabular}

\section{Introduction}

Al-Al Bayt University is considered as one of the governmental Jordanian universities that affiliated to the Ministry of Higher Education and Scientific Research, it enjoys legal personality and it is financially and administratively independent, and, in such capacity, it entitles the right to own and dispose movable and immovable property necessary to achieve its objectives, enter into contracts, borrowing with the consent of the Council of Ministers, and the acceptance of aid, donations, gifts, grants and bequests and take all legal actions, including the right to litigate, and appoint the civil public prosecutor or any other attorney as its representative in judicial proceedings, it is a non-profit institution and had a governmental financial bylaw (Article (3) of the Jordanian Universities Act No. (20) for the year 2009).

Most of the Jordanian public universities have witnessed a significant decline in the financial performance in recent times in the light of the difficult economic conditions that the Kingdom passes by in general and the public university in particular, including Al Al-Bayt University, in addition to the rationalization of governmental support for universities and the decrease of the university fees for some disciplines, and the lack of support from private companies in Jordan and so-called social responsibility, these factors had played a key role in the decline of the financial performance for the public Jordanian universities. 


\subsection{Problem of the Study}

The problem of the study represented in finding the appropriate solutions to raise and improve the financial performance of Jordanian Al Al-Bayt University in light of the difficult circumstances of the financial and economic crises that face the country and some of the public Jordanian universities, so this study came to shed the light on the factors that affect the improvement of the financial performance in the Jordanian Al Al-Bayt University through answering the following key questions:

The First Question: Do the rationalization of expenditures affect the improvement of the financial performance in Al Al-Bayt University?

The Second Question: Are the increase of revenues affect the improving of financial performance in the Jordanian Al Al-Bayt University?

\subsection{Objectives of the Study}

The study aims to identify the effecting factors in improving financial performance in the Jordanian Al Al-Bayt University, through the following main and sub-goals:

1. Identify the impact of rationalization of expenditures on improving the financial performance at $\mathrm{Al}$ Al-Bayt University.

2. Identify the impact of increasing revenues on improving the financial performance at Al Al-Bayt University.

\subsection{Significance of the Study}

The significance of the study derives from the financial crises experienced by some governmental Jordanian universities in general and Al Al-Bayt University in particular, it will shed light on the factors influencing the improving of financial performance of Al Al-Bayt University, in order to determine those factors that have a great impact on improving financial performance and finding the appropriate solutions to raise the university's ability to face the increasing fiscal deficit.

The significance of this study also lies in that it is the first one in Jordan which addressed the financial performance in universities as far as the researcher knew.

\subsection{Hypotheses of the Study}

The First Hypothesis: The rationalization of expenditures does not affect the improving of financial performance at Al Al-Bayt University.

The Second Hypothesis: The increase in revenue does not affect the improving of financial performance at Al Al-Bayt University.

Study Outline:

Independent Variables Dependent Variable

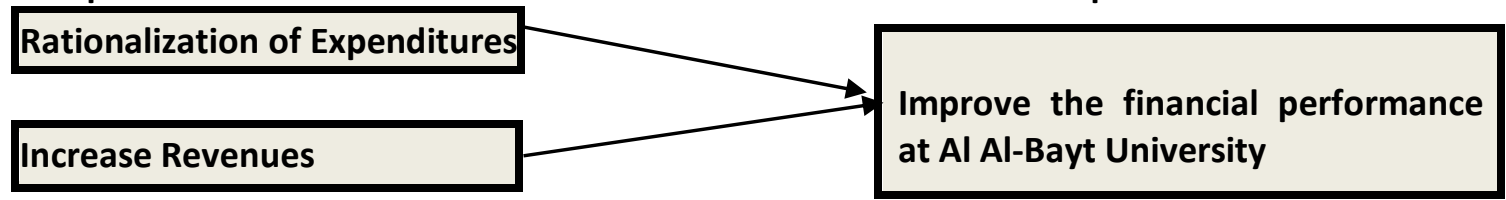

Figure 1. Framework of the hypotheses

\section{Literature review}

Previous studies were arranged chronologically from newest to oldest:

One of the fundamental issues facing research universities is to raise productivity of their research community. A thorough study of the literature reveals that there are many articles on productivity, however, there are only a small number of them are relate to productivity issues affecting researchers in universities. In our work, we aim to use cloud computing services as a tool to help improve productivity of research activities. This is accomplished by identifying and addressing the main factors that influence 
improvement in productivity and identified researchers' needs from cloud computing services and applications. To obtain the needs and the factors affecting the productivity of university researchers, we conducted interviews with postgraduate students to determine them. In this paper, we report our findings on the important needs of researchers from cloud services for productivity improvement and the factors that have a negative influence on productivity in addition to suggestion resolving study problem (Alkhansa, et al., 2015).

An important priority of public policy is to ensure that higher education institutions contribute to economic growth and social progress as a whole, especially in the context of today's globalized markets and knowledge economy. It is crucial for any nation to have a good education system and strategic planning to improve learning outcomes, access to facilities, and efficient use of resources. This paper explained the rationale for change in funding higher education with comparison made based on previous literature in developed and developing countries (Abd Rahman et al., 2013).

The study explored the relationship between target costing and competitiveness at Jordanian Private Universities. The research question regarding target costing focused on leadership of target selling price, customer needs, degree of developing a team work, cost of the product life cycle, stage of product design and value chain development. A questionnaire was used to elicit data. Two scales were used to measure the estimates by financial managers, directors of planning and quality, and heads of accounting departments in the universities. The sample size was 50 subjects, and response rate was $80 \%$. Findings of the study indicated that: universities have a medium target costing dimensions of (3.48); the dimension of target selling price leadership was the highest and reducing the life cycle of university specialization was the lowest; universities enjoy a medium competitive advantages with a score of (3.46); and expansion in specializations was the highest in performance and university's specializations cost was the weakest. Results showed a significant difference in the strength of links between the dimensions of the target costing technique and the dimensions of strengthening the competitive advantage. Recommendations suggested that universities in general and Jordanian Private Universities in particular, have to activate the dimensions of target costing technique to achieve the competitive advantages and promote it (Al-Awawdeh ad Al-Sharairi, 2012).

Higher education represents a major and central importance in countries' economies. This importance begins to influence the philosophy of higher education institutions and their role in achieving community development and the role played by them in the national economy and in the competitiveness of this economy at the international level. This study examines the competitiveness of institutions of higher education and proposes a framework that can guide these institutions to the new role that they must exercise; it also examines the reality and indicators of Saudi government universities in light of the proposed framework (Al-Saleh, 2012).

The study aimed to identify the extent of the investment funds commitment in the Jordanian public universities to implement the accounting disclosure requirements, a questionnaire has been designed for this purpose and distributed to preparers of financial statements, who are (40), the recovered questionnaires which were appropriate for analysis reached (36) questionnaires, with a recovery percentage of $(90 \%)$ ).A questionnaire data was analyzed by using a (SPSS) and a number of statistical techniques through descriptive statistics, arithmetic means, standard deviations and percentages, in addition of using the (One-Sample-T Test) to examine the hypotheses of the study. The results of the study showed that the obligation to apply the accounting disclosure requirements have been achieved with low degree and that there are constraints limiting the commitment of investment funds in Jordanian public universities in applying the accounting disclosure requirements. The most important recommendations of the study are the need to work on the independency of investment funds from the university administration, thus contributing to begin applying the accounting disclosure requirements (Al-Sharairi, 2012).

The objective of this research (The Possibility of Applying the Costs System based on the Activities in Jordanian Universities and the Obstacles to its Implementation) is to identify the possibility of applying the cost system based on the activities of Jordanian universities in allocating costs, controlling them, taking advantage of them in rationalizing these costs, the obstacles that impede its implementation, means and the necessary steps to apply them. The questionnaire was used to collect data from 20 official and private Jordanian universities, the search found that the Jordanian universities do not apply the costs system based 
on activities and they uses a special tab depending on their ownership. The application of the system faces many difficulties ranging from high to medium degree, it can be divided into difficulties concerning management, qualification and the staff working in departments and financial units and technical difficulties related to the system. The degree of importance of the difficulties in applying the cost system based on the activities in the Jordanian universities is not different according to the ownership of the university, whether private or official. The study recommended several recommendations, such as the need for Jordanian universities to implement the cost system based on the activities to take advantage of its positive advantages over its activities to improve the planning and control of costs, the preparation of realistic budgets, drawing of plans objectively to help in the development of the teaching process and raise the quality level and overcome the difficulties facing the application and provide the basic elements of its application (Al-Sharari, 2007).

An entrepreneurial university must undertake two tasks: it must train future entrepreneurs, persons who will found their own businesses, and also develop an entrepreneurial spirit in students in all subject areas. Second, it must operate in an entrepreneurial manner itself, organizing business incubators, technology parks, and the like, involving students in these organizations and, through them, assisting students and graduates in the founding of businesses. Financial assistance to start-ups should eventually be repaid to the given university from the profits made by the maturing companies and then be reinvested in new start-ups. Thus the entrepreneurial university will contribute to the development of its region, and through co-operation with other entities, to economic development in general (Shulte and Peter, 2004).

\subsection{Theoretical Literature}

\section{First: Expenditures}

The researcher finds that the expenses in general are the money spent by the organization or the company or the institution, whether cash or for terms or exchange of services, in order to obtain the purpose of maintenance, whether for one period (Revenue) or for several periods (Capital), so the distinction must be made between the expenditures spent by the profit institutions and which in turn, the principle of meeting expenditures with income is applied, while the expenditures of state institutions, including public universities are somehow different, where the main objective is to provide services to citizens. The expenditures should be also distinguished from spending, since the expenditure is what is actually paid and which appeared within the terms of the final account in the government sector, while spending is the amount allocated for future benefits and appear within the budget lines.

Based on the above, expenditures of Al-Bayt University are classified in (final account of Al-Bayt University 2016) to:

\section{A. Recurrent Expenditure:}

- Salaries, allowances and wages expenses that include: Salaries and allowances of faculty members, salaries and allowances of the administrative body, allowances for the increase of expected salaries, allowances for incentives and parallel reserve, wages, bonuses and rental services.

- Compensation expenses and insurance for employees that include: Contribution in the savings fund, contribution in social security, contribution in health insurance for employees, contribution in life insurance of employees, and contribution to end of service benefits for employees.

- Supplies, tasks and maintenance expenses, include: Maintenance of scientific laboratories, maintenance of hardware and computer infrastructure, general maintenance materials and supplies, hygiene and protection items, users' clothing, stationery, inks and office supplies, catering supplies for restaurants and cafeterias, agricultural materials and supplies, campus improvements, maintenance of networks and agricultural spare parts, and general supplies.

- Supporting funds, services and student activities, include: Different student activities, support of student funds, student health insurance, student life insurance, student publications, university contribution of university fees, university contribution of student council budget, public and private accreditation allowances and contribution to the development of career guidance and follow-up of graduates.

- Joint public expenditures, include: Common consumer expenditures, insurance of movable and immovable assets of the University, expenses of official delegations and hospitality, expenses of vehicles, 
declarations and publications, contracts and subscriptions to international and local information networks, miscellaneous supplies and purchases and common consumer expenditures.

- Contributions in Arab federations and associations include: Contributing in Arab and international federations, contributing in Arab and international university ties, and contributing in other activities and services.

- Recurrent expenditure commitments from previous years that include: Recurrent expenditures obligations from previous years.

- Interest and bank commissions that include: Interest on the current debtor.

- Repayment of the loan and interest of the provident fund include: Repayment of loans and repayment of loan interest.

B. Scientific Research Expenditures:

C. Scientific Missions Expenditures:

D. Capital Expenditures that include: Variety of licenses, development of various technologies (servers, software ...), office equipment and furniture, hardware and equipment, expenditures related to various parties of the university, special equipment for student accommodation, various vehicles, special equipment, spare parts, raw materials, buildings, development projects, warehouses and hangars, preparation of preliminary plans, development of sports stadiums project, agricultural projects and water lines, expansion and development of infrastructure and rehabilitation of existing buildings, establishment of umbrellas, carried forward capital expenditures and liabilities.

\section{Second: Revenues:}

The researcher finds that revenues in general are money which are collected by the organization, the company or the institution, whether cash or forward or exchange services for the sake of service or goods to others, which added to the net income distributable to the shareholders, so we should distinguish between the concept of revenue obtained by institutions for profit and revenue obtained by the state's institutions, including government universities, which is different in concept, and the main purpose is to distribute those revenues to the financial burden of the university.

Based on the above, the income is classified in Al-Al Bayt University to (Al-Al Bayt University balance sheet for the year 2016):

1. Self-Revenue:

- University fees include: university fees/normal system, university fees/evening system, university fees /parallel system, university fees/International master degree, university fees/normal master degree, university fees/International PhD, university fees/Normal PhD, university fees/Higher diploma and due university fees.

- Movable and immovable property revenues include: bank credit interest, revenues of restaurants and cafeterias, revenues of resident status, rent of university buildings and facilities, and rental income for sites due from prior years.

- Other revenues include: Miscellaneous revenues, language center revenues, Center for Consultancy and Technical Services and Community Development revenues, Amman Studies Unit.

B. Subsidy:

C. Donations and Grants:

Third: Financial Performance at Al-Bayt University:

The researcher finds that the financial performance at Al-Bayt University depends primarily on selfrevenues and comes secondly subsidies and then donations and grants at the third class, which was observed in the final accounts of the University during the last three years, but with a clear increase in expenditures, and this reflect a poor financial performance and a shortage is accumulating, where a good financial performance lies in the ability of senior management and decision makers to utilize the available resources and expand the university's long-term investments by exploiting the university's lands by establishing an integrated investment city, that will increase self-revenues. 


\section{Methodology of research}

The researcher designed a questionnaire by developing questions that fit all the variables of the study and distributed to employees at Al-Bayt University, specifically those who are working in the financial department, the Internal Control Department, the Investment Fund Department and the faculty members of the Faculty of Economics and Administrative Sciences.

\subsection{Population and Sample of the Study}

The population and the sample of employees in represented in the Finance Department, the Internal Control Department, the Investment Fund Department and the faculty members of the Faculty of Economics and Administrative Sciences. The researcher distributed (60) questionnaires, and (45) samples were retrieved for analysis, with a (75\%) recovery rate.

\subsection{Description of Study Sample Characteristics}

Table 1. Characteristics of the Study Sample

\begin{tabular}{|c|c|c|c|}
\hline Item & variable & Number & Ratio \% \\
\hline \multirow[t]{2}{*}{ Gender } & Male & 39 & 86.7 \\
\hline & female & 6 & 13.3 \\
\hline Total & & 45 & 100 \\
\hline \multirow[t]{4}{*}{ Age } & Less than 25 & 2 & 4.4 \\
\hline & From 25 - less than 35 & 12 & 26.6 \\
\hline & From 35 - less than 45 & 14 & 31.2 \\
\hline & More than 45 & 17 & 37.8 \\
\hline Total & & 45 & 100 \\
\hline \multirow{4}{*}{$\begin{array}{l}\text { Experience at the } \\
\text { University }\end{array}$} & - Less than 5 years & 6 & 13.3 \\
\hline & $-5-10$ years & 11 & 24.5 \\
\hline & $-10-15$ years & 10 & 22.2 \\
\hline & -15 years and above & 18 & 40 \\
\hline Total & & 45 & 100 \\
\hline \multirow[t]{9}{*}{ Job title } & Manager & 3 & 6.7 \\
\hline & Head of the Department & 8 & 17.8 \\
\hline & Head of Division & 4 & 8.8 \\
\hline & Assistant Director & 3 & 6.7 \\
\hline & Assistant Head of the Department & $\mathbf{0}$ & $\mathbf{0}$ \\
\hline & Assistant Division Chief & 0 & 0 \\
\hline & Employee & 7 & 15.5 \\
\hline & Teaching Staff & 20 & 44.5 \\
\hline & Other & 0 & 0 \\
\hline Total & & 45 & 100 \\
\hline \multirow[t]{5}{*}{ Qualification } & High School & $\mathbf{0}$ & $\mathbf{0}$ \\
\hline & Average Diploma & $\mathbf{0}$ & 0 \\
\hline & BA & 11 & 24.5 \\
\hline & M.A. & 11 & 24.5 \\
\hline & Ph.D. & 23 & 51 \\
\hline Total & & 45 & 100 \\
\hline \multirow[t]{5}{*}{ Scientific specialization } & Accounting & 27 & 60 \\
\hline & Administration & 6 & 13.3 \\
\hline & Finance and Banking & 6 & 13.3 \\
\hline & Economic & 6 & 13.4 \\
\hline & Other & 0 & 0 \\
\hline Total & & 45 & 100 \\
\hline
\end{tabular}


We note from table 1 above that the majority of the study sample is male with a rate of (86.7\%), as for age, the majority is from the age of (45) years, with a rate of $(37.8 \%)$, while the majority of the university experience is (40\%) for more than (15) years, as for the job title, the majority came from the faculty and the ratio was $(44.5 \%)$, while the educational qualification, the majority is from the holders of doctoral degrees, with a rate of $(51 \%)$ and there is no one is less than a bachelor's degree, which means that there is a scientific qualification that enable the sample to answer the questions of questionnaire much better. As for the specialization, we note that the majority of the study sample holds accounting specialization, where the percentage reached (60\%), based on the above; we find that the study sample has sufficient capacity to answer the paragraphs of the questionnaire accurately, in full knowledge of the university's financial situation.

\subsection{Study Variables}

Based on the study problem and its hypotheses, the independent variables represented as the following: rationalization of expenditure and increase of revenues, while the dependent variable is improving the financial performance of Al-Bayt University.

\subsection{Study Tool, Description, Persistence and Credibility}

A tool was designed to achieve the objectives of the study by reviewing the related theoretical literature of the variables of the study, the study tool included two parts: Part One: Related to the demographic factors of the study sample in Table 1.The second part: was devoted to measure the factors affecting the improvement of financial performance. Five-dimensional Likert scale was adopted in the development of the study, the scales of the paragraphs were calculated as the following: (strongly agree) was given ( 5 degrees), and (agree) was given (4 degrees), (moderately agree) was given (3 degree). (Disagree) was given (2 degrees), (strongly disagree) was given (one degree). The data was interpreted as follows: (1-2.49) means low degree, and (2.50-3.49) means a moderate degree, and (3.5-5) means a high degree. The questionnaire was distributed in which its paragraphs was (42) into three areas to include all independent and dependent variables.

\subsection{Statistical Methods}

For the purpose of analyzing the study data, the following statistical methods were used:

Descriptive Analysis: This analysis was based on arithmetic mean, standard deviation, and percentages.

Multiple Regression Analysis: To measure the factors affecting the financial performance of the dependent variable, in order to improve the financial performance of Al-Bayt University. It also used to test the tool of study and its reliability in the testing of hypotheses, and to achieve the objectives of the study, internal consistency scale "Cronbach Alpha" was used; to measure the stability of the responses of the study sample about the questionnaire questions and (Sekaran, 2016) explain the coefficient of internal stability among the responses is that the statistically acceptable value of this measure is $(70 \%)$ and more. The results of the calculation of this coefficient showed that the stability in the areas of the tool was very high, which confirms the possibility of relying on the questionnaire in the test of hypotheses, as shown in the table below:

Table 2. Stability Coefficients in the Cronbach Alpha method for the areas of study

\begin{tabular}{|l|c|c|}
\hline \multicolumn{1}{|c|}{ Field } & $\begin{array}{c}\text { Number of } \\
\text { Questions }\end{array}$ & $\begin{array}{c}\text { Alpha Coefficient } \\
\text { Value }\end{array}$ \\
\hline Rationalization of Expenditures & 17 & 0.838 \\
\hline Increase Revenues & 18 & 0.924 \\
\hline Improving Financial Performance at Al-Bayt University & 7 & 0.842 \\
\hline The Tool as a Whole & 42 & 0.934 \\
\hline
\end{tabular}

Tool credibility means to ensure that the statements contained in the study tool can lead to accurate data collection (Sekaran, 2015). The study tool was presented to a number of specialists in the field of accounting at the Jordanian universities to determine the appropriateness of the paragraphs of the questionnaires linguistically and the extent to which they belong to the dimension within which they were 
established. The observations and opinions of the arbitrators were adopted and some paragraphs were reformulated in the light of these observations. Variance Inflation Factor was used to make sure that there is no correlation between independent variables (Multicolinearity).

Table 3. Test the Strength of the Study Model

\begin{tabular}{|l|c|}
\hline \multicolumn{1}{|c|}{ Model } & VIF \\
\hline Increase Revenues & 1.435 \\
\hline Improving Financial Performance at Al - Bayt University & 1.435 \\
\hline
\end{tabular}

Since the value of (VIF) is less than (4) for all variables, this means that there is no overlap between the independent variables, reflecting the strength of the study model.

\subsection{Data Analysis Related to Study Fields}

Table 4. First Field: Rationalization of Expenditure $(n=45)$

\begin{tabular}{|c|c|c|c|c|}
\hline No. & Rationalization of Expenditures & $\begin{array}{c}\text { Arithmetic } \\
\text { Means }\end{array}$ & $\begin{array}{l}\text { Standard } \\
\text { Deviation }\end{array}$ & Ranking \\
\hline 1 & $\begin{array}{l}\text { Reducing the replacement and renewal of machinery and } \\
\text { equipment contributes in improving the financial performance of } \\
\text { the university. }\end{array}$ & 3.51 & 1.22 & 9 \\
\hline 2 & $\begin{array}{l}\text { Spending on the development of buildings in the } \\
\text { university contributes in improving financial performance. }\end{array}$ & 3.84 & 0.90 & 3 \\
\hline 3 & $\begin{array}{l}\text { The application of accounting methods and procedures in profit- } \\
\text { oriented companies improve the financial performance of the } \\
\text { university. }\end{array}$ & 3.84 & 0.98 & 3 \\
\hline 4 & $\begin{array}{l}\text { Reducing the overtime work in some administrative departments } \\
\text { and colleges at the university improves financial performance. }\end{array}$ & 3.80 & 0.79 & 5 \\
\hline 5 & $\begin{array}{l}\text { Rationalizing of salaries and allowances of the teaching and } \\
\text { administrative bodies contribute in improving the financial } \\
\text { performance of the university. }\end{array}$ & 3.24 & 1.23 & 13 \\
\hline 6 & $\begin{array}{l}\text { Rationalizing incentives and parallel reserves improve the financial } \\
\text { performance of the university. }\end{array}$ & 2.98 & 1.23 & 15 \\
\hline 7 & $\begin{array}{l}\text { Rationalizing of wages, bonuses and rental services improve } \\
\text { financial performance at the university. }\end{array}$ & 3.27 & 1.30 & 11 \\
\hline 8 & $\begin{array}{l}\text { Rationalizing the University's contribution to compensation and } \\
\text { insurance for employees improves financial performance. }\end{array}$ & 2.80 & 1.12 & 17 \\
\hline 9 & $\begin{array}{l}\text { Rationalizing the value of supplies and equipment improve financial } \\
\text { performance at the university. }\end{array}$ & 3.80 & 1.04 & 5 \\
\hline 10 & $\begin{array}{l}\text { Rationalizing the university's contribution in supporting funds, } \\
\text { services and student activities improve the financial performance } \\
\text { of the university }\end{array}$ & 3.42 & 1.01 & 10 \\
\hline 11 & $\begin{array}{l}\text { Rationalizing common expenses such as hospitality, insurance } \\
\text { supplies, university assets, etc. improve financial performance. }\end{array}$ & 3.76 & 1.09 & 7 \\
\hline 12 & $\begin{array}{l}\text { Rationalizing the University's contribution to Arab and international } \\
\text { associations and associations improve financial performance. }\end{array}$ & 3.27 & 1.27 & 11 \\
\hline 13 & $\begin{array}{l}\text { Reducing the recycling of recurring expenses from previous years } \\
\text { improve financial performance. }\end{array}$ & 3.76 & 1.09 & 7 \\
\hline 14 & $\begin{array}{l}\text { Minimizing borrowing, which in turn increases city benefits and } \\
\text { burdens on the university, improves financial performance. }\end{array}$ & 4.24 & 1.11 & 1 \\
\hline 15 & $\begin{array}{l}\text { Rationalizing the expenses of the university's contribution in } \\
\text { supporting scientific research improve financial performance. }\end{array}$ & 2.89 & 1.23 & 16 \\
\hline 16 & $\begin{array}{l}\text { Rationalizing the expenses of scientific missions improve the } \\
\text { financial performance of the university. }\end{array}$ & 3.20 & 1.08 & 14 \\
\hline 17 & $\begin{array}{l}\text { Expenditures on capital projects (alternative power plants, } \\
\text { purification plants, water wells, etc.) rationalize the expenditures, } \\
\text { which improve the financial performance of the university. }\end{array}$ & 3.96 & 1.30 & 2 \\
\hline \multicolumn{2}{|r|}{ Total field/Rationalization of Expenditure } & 3.50 & 0.59 & \\
\hline
\end{tabular}


Table 4 shows that the measure of rationalization of expenditure in all paragraphs reached an average of (3.50). The mean ranged between (4.24-2.80). Paragraph (14) ranked first, with an arithmetic mean of (4.24), paragraph (17) came in second, with the mean of (3.96), and paragraph (8) came in last place, with an arithmetic mean of (2.80). The total arithmetic mean/rationalization of expenditure reached (3.50).

Table 5. Second Field: Revenue Increase $(n=45)$

\begin{tabular}{|c|c|c|c|c|}
\hline No. & Increase Revenues & $\begin{array}{l}\text { Arithmetic } \\
\text { Means }\end{array}$ & $\begin{array}{l}\text { Standard } \\
\text { Deviation }\end{array}$ & Ranking \\
\hline 18 & $\begin{array}{l}\text { Increasing the university's share of governmental support improves } \\
\text { the financial performance of the university. }\end{array}$ & 4.56 & 0.76 & 8 \\
\hline 19 & $\begin{array}{l}\text { Increasing the fees for the credit hours of some } \\
\text { required specializations improve the financial performance at the } \\
\text { university. }\end{array}$ & 4.67 & 0.71 & 3 \\
\hline 20 & $\begin{array}{l}\text { Freezing of non-required specialties in the labor market improve the } \\
\text { financial performance of the university. }\end{array}$ & 3.84 & 1.21 & 18 \\
\hline 21 & $\begin{array}{l}\text { Presenting new required disciplines in the labor market improve the } \\
\text { financial performance of the university. }\end{array}$ & 4.73 & 0.58 & 1 \\
\hline 22 & $\begin{array}{l}\text { Increasing obtaining donations and grants improve financial } \\
\text { performance at the university. }\end{array}$ & 4.64 & 0.80 & 5 \\
\hline 23 & $\begin{array}{l}\text { Collecting Accrued Revenues from previous years improve financial } \\
\text { performance at the university. }\end{array}$ & 4.67 & 0.74 & 3 \\
\hline 24 & $\begin{array}{l}\text { Expanding available programs such as international graduate } \\
\text { programs improve financial performance at the university. }\end{array}$ & 4.58 & 0.78 & 6 \\
\hline 25 & $\begin{array}{l}\text { Establishing international programs for the bachelor's } \\
\text { degree improve financial performance at the university. }\end{array}$ & 4.51 & 0.84 & 9 \\
\hline 26 & $\begin{array}{l}\text { Investing the university's lands through the establishment of } \\
\text { investment projects will improve the financial performance at the } \\
\text { university. }\end{array}$ & 4.71 & 0.73 & 2 \\
\hline 27 & $\begin{array}{l}\text { Reducing the delay in collecting university fees improve the } \\
\text { financial performance of the university. }\end{array}$ & 4.13 & 0.99 & 16 \\
\hline 28 & $\begin{array}{l}\text { The integration of some departments, colleges and university } \\
\text { departments improve financial performance. }\end{array}$ & 4.18 & 1.15 & 14 \\
\hline 29 & $\begin{array}{l}\text { Establishing medical and pharmaceutical colleges that improve } \\
\text { financial performance in the university. }\end{array}$ & 4.49 & 0.89 & 10 \\
\hline 30 & $\begin{array}{l}\text { Promoting the university in other countries improve the financial } \\
\text { performance of the university. }\end{array}$ & 4.58 & 0.69 & 6 \\
\hline 31 & $\begin{array}{l}\text { Improving the role of some university centers (such as consulting } \\
\text { and community service, Amman studies, languages, computers, } \\
\text { etc.) improve the financial performance of the university. }\end{array}$ & 4.36 & 1.00 & 11 \\
\hline 32 & $\begin{array}{l}\text { Increasing support for investment funds at the university improve } \\
\text { financial performance. }\end{array}$ & 4.27 & 0.94 & 13 \\
\hline 33 & $\begin{array}{l}\text { Increasing cooperation agreements with prestigious international } \\
\text { universities improve financial performance at the university. }\end{array}$ & 4.16 & 0.88 & 15 \\
\hline 34 & $\begin{array}{l}\text { Reducing unjustified discounts offered by the university to others } \\
\text { improve financial performance. }\end{array}$ & 4.29 & 0.92 & 12 \\
\hline 35 & $\begin{array}{l}\text { Increasing the establishment of recreational projects in and around } \\
\text { the university improves financial performance. }\end{array}$ & 4.07 & 0.94 & 17 \\
\hline \multicolumn{2}{|r|}{ Total Field/Revenues Increase } & 4.41 & 0.58 & \\
\hline
\end{tabular}

Table 5 shows that the measure of revenues' increase in all paragraphs amounted to (4.41), arithmetic mean ranged between (4.73-3.84), paragraph (21) ranked first, with an arithmetic mean of (4.73), which is the highest of the arithmetic means, paragraph (26) ranked second, the mean was (4.71), and the paragraph (20) in the last place, with an arithmetic mean of (3.84).The total field/revenue increase ratio was (4.41). 
Table 6. Field No. 3: Improving Financial Performance at Al-Bayt University $(\mathrm{N}=45)$

\begin{tabular}{|c|c|c|c|c|}
\hline No. & Improving Financial Performance at Al-Bayt University & $\begin{array}{l}\text { Arithmetic } \\
\text { Means }\end{array}$ & $\begin{array}{l}\text { Standard } \\
\text { Deviation }\end{array}$ & 涚 \\
\hline 36 & $\begin{array}{l}\text { Senior management at the university adoption of the optimal utilization } \\
\text { of available financial resources contributes in the improvement of } \\
\text { financial performance. }\end{array}$ & 4.44 & 0.72 & 1 \\
\hline 37 & $\begin{array}{l}\text { The re-examination and analysis of the final accounts for previous years } \\
\text { contribute in improving the financial performance of the university. }\end{array}$ & 3.98 & 0.78 & 5 \\
\hline 38 & Effective control improves the financial performance of the university. & 4.38 & 0.94 & 2 \\
\hline 39 & $\begin{array}{l}\text { The university administration keenness in the implementation of the } \\
\text { plans to contribute in improving the financial performance. }\end{array}$ & 4.20 & 1.01 & 4 \\
\hline 40 & $\begin{array}{l}\text { The cancellation of some of the budget items imposed contributes in the } \\
\text { improvement of financial performance at the university. }\end{array}$ & 3.84 & 1.04 & 7 \\
\hline 41 & $\begin{array}{l}\text { The University administration's keenness in controlling the employees' } \\
\text { commitment to implement the university's directions contributes in } \\
\text { improving financial performance. }\end{array}$ & 3.98 & 1.06 & 5 \\
\hline 42 & $\begin{array}{l}\text { The administration of the university is keen on assigning people who are } \\
\text { capable of making changes to improve financial performance. }\end{array}$ & 4.24 & 1.15 & 3 \\
\hline \multicolumn{2}{|r|}{ Total Field/Improving Financial Performance at Al-Bayt University } & 4.15 & 0.69 & \\
\hline
\end{tabular}

Table 6 shows that the degree of measurement of financial improvement performance at Al-Bayt University in all paragraphs reached (4.15), the arithmetic mean ranged between (4.44-3.84), paragraph (36) ranked first, with an arithmetic mean (4.44), the highest of the arithmetic mean, and paragraph (38) ranked second, with an arithmetic mean (4.44), which is the highest arithmetic mean, paragraph (38) ranked second, with an arithmetic mean of (4.38), and paragraph (40) came last, with an arithmetic mean of (3.84). The mathematical mean of the total field/improvement of financial performance at Al-Bayt University were (4.15).

Table 7. Results of Multiple Linear Regression Testing of Factors Affecting Improving Financial Performance at Al-Bayt University $(\mathrm{N}=45)$

\begin{tabular}{|c|c|c|c|c|c|c|c|c|c|}
\hline $\begin{array}{l}\text { Independent } \\
\text { variables }\end{array}$ & $\begin{array}{c}\text { Coefficient } \\
\text { of } \\
\text { Correlation } \\
\text { (r) }\end{array}$ & $\begin{array}{c}\text { The } \\
\text { Coefficient } \\
\text { of } \\
\text { Determinati } \\
\text { on } \\
\text { (R 2) }\end{array}$ & $\begin{array}{c}\text { Regressio } \\
n \\
\text { Coefficient } \\
\beta\end{array}$ & $\begin{array}{l}\text { The } \\
\text { standard } \\
\text { coefficien } \\
\text { t (Beta) }\end{array}$ & $\begin{array}{c}(\mathrm{T}) \\
\text { Calculate } \\
\text { d Value }\end{array}$ & $\begin{array}{c}\text { Statistical } \\
\text { Significanc } \\
\text { e } \\
\text { (a) }\end{array}$ & $\begin{array}{c}\quad(F) \\
\text { Calculate } \\
\text { d Values }\end{array}$ & $\begin{array}{c}\text { Statistical } \\
\text { Significanc } \\
\text { e }\end{array}$ & $\begin{array}{l}\text { Result of } \\
\text { Testing the } \\
\text { null } \\
\text { Hypothese } \\
\text { s }\end{array}$ \\
\hline $\begin{array}{l}\text { Rationalization } \\
\text { of Expenditures }\end{array}$ & \multirow{2}{*}{0.742} & \multirow{2}{*}{0.550} & 0.149 & 0.127 & 1.02 & 0.310 & \multirow{2}{*}{25.69} & \multirow{2}{*}{0.000} & \multirow{2}{*}{ Reject } \\
\hline $\begin{array}{c}\text { Increase the } \\
\text { Revenues }\end{array}$ & & & 0.795 & 0.664 & 5.35 & 0.000 & & & \\
\hline
\end{tabular}

Table 7 shows that the value of $(R)$ was $(0.742)$, indicating a high degree of correlation between the factors affecting and improving financial performance at Al-Bayt University. The value of ( $R$ Square) was (0.550), which is a good ratio and explains the ability of factors that affect the improvement of financial performance at the Al-Bayt University. The value of the test (F) was (25.69), which is a statistically significant value at the level of significance of $(\alpha=0.05)$, therefore, it is concluded that there is a statistically significant impact of two independent variables on improving financial performance at Al-Bayt University.

The First Variable (Rationalization of Expenditures): The value of $(\beta)$ is $(0.127)$ and the value of $(T)$ is (1.02), which is a positive value and is not statistically significant at the significance level $(\alpha=0.05)$, and this indicates that there is no impact of the variable rationalization of expenditures in improving financial performance at Al-Bayt University. The researcher believes that the reason is due to some of the answers for this variable, the impact is very low.

The Second Variable (Increase Revenue): The value of $(\beta)$ is (0.664) and the value of $(T)$ is (5.35), which are positive values and statistically significant at the level of significance $(\alpha=0.05)$, and this indicates an 
impact of increasing the income variable in improving financial performance at Al-Bayt University. The researcher believes that the reason is that the majority of the answers to this impact variable are very high.

\section{Results}

In light of the above, the study showed that the factors of rationalization of expenditure and increase in revenues are effective in improving the financial performance of Al-Bayt University, with different ratios between independent variables.

1. The increase revenues variable affects the improvement of financial performance at Al-Bayt University, where the arithmetic mean of this variable is (4.41).

2. The rationalization of expenditures variable does not affect the improvement in financial performance at Al-Bayt University, since the arithmetic mean of this variable is (3.50).

\section{Recommendations}

1. The need to develop new and required specializations at Al-Bayt University in the local and Arab labor market.

2. The need to raise the fees of credit hours for the required disciplines, which increase the university's revenues.

3. Working on the investment of the university lands through the establishment of investment projects, which in turn will improve the university's revenues.

4. The need to establish medical and pharmaceutical science colleges, which will inevitably increase the university's revenues.

5. The need to reduce the borrowing, which in turn increases the interest charge and the burdens of the university.

6. The need to cancel some imposed items of the budget to contribute in increasing revenues and reduce the burden on the university.

\section{References}

1. Al-Awawdeh \& Al-Sharairi , W., J. (2012). The Relationship between Target Costing and Competitive Advantage of Jordanian Private Universities" International Journal of Business and Management, Vol. 7, No. 8; April 2012,pp123-142.

2. Abd Rahman, A., Alan F., Moonsamy, N., (2013). Funding Crisis In higher Education Institutions: Rationale for Change, Asian Economic and Financial Review 2(4):489-503.

3. Al-Saleh, O. (2012). Competitiveness of higher education institutions: a proposed framework Journal of the researcher, number 10/2012, University of Majmaa, Saudi Arabia.

4. Al-Shurairy, J. (2007). The Possibility of Applying the Cost-based system of (ABC) activities In Jordanian Universities and the Obstacles to its Application, Egyptian Journal of Commercial Studies, Mansoura University, Egypt, Issue 2, Vol. 31, pp. 65-96.

5. Al-Sharairi, J. (2012). The Commitment of Investment Funds in Implementation of Accounting Disclosure Requirement at Jordanian State Universities, The Business Review, Cambridge, USA, Vol. 20, No.2, December 2012 , pp.124-134.

6. Jordanian universities Law No. (20) For the year 2009, published in the Official Gazette No. (4980) date of 06/09/2009.

7. Sekraran, U. (2016). Research Method for Business: A Skill Building Approach, 8th Edition, John Wiley and Sons, New York.

8. Shakeabubakor, A.A., Sundararajan, E., and Hamdan, A. R. (2015). Cloud Computing Services and Applications to Improve Productivity of University Researchers, International Journal of Information and Electronics Engineering, Vol. 5, No. 2, March 2015.

9. Shulte, P. (2004). The Entrepreneurial University: A Strategy for Institutional Development, Higher Education in Europe, Vol., 29, No. 2, 2004. DOI: 10.1080/0379772042000234811. 